\title{
Seasonal dynamics of natural Ostreococcus viral infection at the single cell level using VirusFISH
}

Yaiza M. Castillo ${ }^{1}$, Irene Forn ${ }^{1}$, Sheree Yau ${ }^{1}$, Xosé Anxelu G. Morán ${ }^{2}$, Laura AlonsoSáez ${ }^{3,4}$, Néstor Arandia-Gorostidi ${ }^{3,5}$, Dolors Vaqué ${ }^{1}$, and Marta Sebastián ${ }^{1,6}$

\section{Author affiliations}

${ }^{1}$ Department of Marine Biology and Oceanography, Institute of Marine Sciences (CSIC), Barcelona, Spain.

${ }^{2}$ King Abdullah University of Science and Technology (KAUST), Red Sea Research Center, Thuwal, Saudi Arabia.

${ }^{3}$ Centro Oceanográfico de Gijón/Xixón, IEO, Gijón/Xixón, Spain.

${ }^{4}$ AZTI Marine Research, Basque Research and Technology Alliance (BRTA), Txatxarramendi ugartea z/g, Sukarrieta, Spain.

${ }^{5}$ Department of Earth System Science, Stanford University, Stanford, CA, USA.

${ }^{6}$ Institute of Oceanography and Global Change (IOCAG), University of Las Palmas de Gran Canaria (ULPGC), Telde, Spain.

Corresponding authors: Yaiza M. Castillo and Marta Sebastián. Department of Marine Biology and Oceanography, Institut de Ciències del Mar (CSIC), Passeig Marítim de la Barceloneta, 37-49, Barcelona E-08003, Catalonia, Spain. E-mail: yaiza@icm.csic.es, msebastian@icm.csic.es

Running title: Viral infection of Ostreococcus populations.

The authors declare no conflict of interest

This article has been accepted for publication and undergone full peer review but has not been through the copyediting, typesetting, pagination and proofreading process which may lead to differences between this version and the Version of Record. Please cite this article as doi: 10.1111/1462-2920.15504 


\title{
SIGNIFICANCE STATEMENT
}

One of the major challenges in viral ecology is the detection of viral-host interactions in complex communities, with the aim of assessing the impact of viruses in the populations of their host. Here we present the proof of concept that Virus fluorescence in situ hybridization (VirusFISH) can be used to visualize and monitor viral infection dynamics in natural occurring populations of Ostreococcus, a cosmopolitan picoeukaryote that form occasional blooms in nature. This technique can be easily implemented for other viralhost systems, allowing to visualize their interaction at the single-cell level.

\begin{abstract}
Ostreococcus is a cosmopolitan marine genus of phytoplankton found in mesotrophic and oligotrophic waters, and the smallest free-living eukaryotes known to date, with a cell diameter close to $1 \mu \mathrm{m}$. Ostreococcus has been extensively studied as a model system to investigate viral-host dynamics in culture, yet the impact of viruses in naturally occurring populations is largely unknown. Here, we used Virus Fluorescence in situ Hybridization (VirusFISH) to visualize and quantify viral-host dynamics in natural populations of Ostreococcus during a seasonal cycle in the central Cantabrian Sea (Southern Bay of Biscay). Ostreococcus were predominantly found during summer and autumn at surface and $50 \mathrm{~m}$ depth, in coastal, mid-shelf and shelf waters, representing up to $21 \%$ of the picoeukaryotic communities. Viral infection was only detected in surface waters, and its impact was variable but highest from May to July and November to December, when up to half of the population was infected. Metatranscriptomic data available from the midshelf station unveiled that the Ostreococcus population was dominated by the species $O$.
\end{abstract}


lucimarinus. This work represents a proof of concept that the VirusFISH technique can be used to quantify the impact of viruses on targeted populations of key microbes from complex natural communities.

\section{KEYWORDS}

VirusFISH; natural communities; Ostreococcus spp.; viruses; infection dynamics. 


\section{INTRODUCTION}

Quantifying the in situ impact of viruses on their hosts is one of the major challenges in marine viral ecology, and requires the detection of both specific viruses and their hosts within complex natural communities. Due to the absence of a universal phylogenetic marker for viruses, this has been achieved through PCR amplification of conserved marker genes within specific viral families (Chen and Suttle, 1995; Larsen et al., 2008; Lehahn et al., 2014; Gran-Stadniczeñko et al., 2019), or through metagenomics (e.g. Mizuno et al., 2013; Roux et al., 2017). However, the identity of the viral host from metagenomic data can only be inferred based on the known host of cultured relatives, or by correlation with the presence of potential host sequences (Lima-Mendez et al., 2015; Nishimura et al., 2017). Other recently developed techniques to detect virus-host interactions in complex communities are digital droplet PCR (Lim et al., 2017), and single-cell genomics (Roux et al., 2014; Castillo et al., 2019). Additionally, metatranscriptomics have also been used to follow some infection dynamics (Zeigler Allen et al., 2017; Alonso-Sáez et al., 2018). Yet, the impact of viruses on their host populations, as the proportion of infected cells, is not directly measured by any of those techniques, even though it is crucial information to understand virus-host population dynamics.

Promising alternatives to explore in situ viral-host interactions are phageFISH (Allers et al., 2013), and its variants direct-geneFISH (Barrero-Canosa et al., 2017), VirusFISH (Castillo et al., 2020), or single-molecule FISH (Vincent et al., 2021). Although their use in nature has been limited, phageFISH was recently used to pinpoint the host of an archaeal virus previously identified in an environmental metagenomic dataset (Hochstein et al., 2016) and to demonstrate viral lysis of an autotrophic key player in the Earth's crust (Rahlff et al., 2020). Likewise, single-molecule FISH was recently used to quantify 
active viral infection in an induced Emiliania Huxleyi bloom during a mesocosm experiment (Vincent et al., 2021).

Due to the mounting evidence of the role that viruses may play in phytoplankton bloom termination, quite a lot of attention has been paid to viruses of bloom forming species, like the coccolithophore Emiliania huxleyi (Wilson et al., 2002; Laber et al., 2018; Sheyn et al., 2018). Under high host cell abundances, such as those found in E. huxleyi blooms, the probability of encountering a virus with its host is high, which may result in a fast viral propagation through the host population (Suttle, 2000). By contrast, the impact of viruses on picoeukaryotic hosts that may form occasional blooms but are generally present at low abundances (Zingone, 1999; O’Kelly et al., 2003; Countway and Caron, 2006) could be more challenging, and it has been little explored. A few studies have focused on the spatial and temporal dynamics of viruses targeting those occasional blooming phytoplankton species, particularly Micromonas (Cottrell and Suttle, 1991, 1995; Zingone, 1999; Baudoux et al., 2015) but also Ostreococcus (Bellec et al., 2010). Nevertheless, these studies used either plaque assays or most probable number approaches, and therefore they did not provide direct evidence of in situ interactions between viruses and hosts.

Recently, we implemented VirusFISH to detect, visualize and follow viral-host dynamics of Ostreococcus tauri- Ostreococcus tauri virus 5 (OtV5) in culture (Castillo et al., 2020). Ostreococcus (Mamiellaceae) is the world's smallest free-living eukaryote known, with a cell diameter of $\sim 1 \mu \mathrm{m}$ (Courties et al., 1994; Derelle et al., 2006; Sanchez et al., 2019). The genus comprises several species that can be ubiquitously found from the coast to the open ocean, and from mesotrophic to oligotrophic waters (Demir-Hilton et al., 2011; Tragin and Vaulot, 2019). The number of sequenced Ostreococcus viruses is constantly increasing, and nowadays the complete genomes of many Ostreococcus 
viruses are available (e.g. Derelle et al., 2008, 2015; Weynberg et al., 2011; Monier et al., 2017). Yet, nothing is known about the Ostreococcus virus-host relationships in situ, and how they change over a temporal scale. Our VirusFISH approach combines a Catalyzed Reporter Deposition Fluorescence in situ Hybridization detection of Ostreococcus species with the general OSTREO01 probe (Not et al., 2004) and viral probes originally designed for the detection of OtV5, but that target most Ostreococcus virus sequenced to date (Castillo et al., 2020).

Here we used VirusFISH to study the monthly dynamics of viral infection in natural populations of Ostreococcus over a full seasonal cycle. We demonstrate that VirusFISH is a powerful tool for assessing virus-host interactions in the environment, even when the hosts are present at low abundances.

\section{MATERIALS AND METHODS}

\section{Environmental sampling}

Samples were collected monthly along a coastal-shelf gradient in the Cantabrian Sea (Southern Bay of Biscay, near Xixón, Spain) at three stations: E1, coastal (30 m maximum depth (max depth); 43.58 $\mathrm{N}, 5.61^{\circ} \mathrm{W}$ ), E2, mid-shelf (110 m max depth; 43.67 $\mathrm{N}, 5.58^{\circ}$ W) and E3, shelf (160 m max depth; 43.78 $\mathrm{N}, 5.55^{\circ} \mathrm{W}$ ) (Fig. 1), from January 2011 to December 2012, at the surface (5m) and at 50m depth (except for E1 where the maximum depth was $30 \mathrm{~m})$. Temperature and salinity were measured by a SeaBird 25 CTD. Samples for chlorophyll $a(\mathrm{Chl} a)$ concentration were collected by sequentially filtering $200 \mathrm{~mL}$ seawater onto 20, 2 and $0.2 \mu \mathrm{m}$ polycarbonate filters. Chl $a$ concentration in the picoplankton size fraction (pChl, $<2 \mu \mathrm{m}$ ) corresponded to the amount collected onto 0.2 
$\mu \mathrm{m}$ filters after passing through $20 \mu \mathrm{m}$ and $2 \mu \mathrm{m}$ filters. Filters were kept frozen at $-20^{\circ} \mathrm{C}$ and processed within two weeks, as explained in Calvo-Díaz and Morán (2006). Picoeukaryotic abundances were acquired by flow cytometry using $1.8 \mathrm{~mL}$ subsamples fixed with paraformaldehyde + glutaraldehyde $(1 \%$ and $0.5 \%$ final concentration, respectively) as described in (Calvo-Díaz and Morán, 2006). A total of 120 samples for Chl $a$ and picoeukaryotic abundances were analyzed.

\section{VirusFISH: sample preparation, labeling and analysis}

Samples for FISH (4 mL) were collected at surface and at $50 \mathrm{~m}$ depths from the 3 different stations (except for E1, where the maximum depth was 30m) from January to December 2012, as described in (Arandia-Gorostidi et al., 2017). Samples were fixed with 3\% freshly filtered formaldehyde and cells were collected onto $0.2 \mu \mathrm{m}$ pore-size polycarbonate filters. Filters were kept at $-80^{\circ} \mathrm{C}$ until their analysis. These samples were originally collected to perform FISH on bacterial groups which explains the low volume filtered. For the VirusFISH, cells and viruses were hybridized and analyzed as described in (Castillo et al., 2020). Briefly, samples were treated with alcohols to remove pigments, then cells were hybridized with the OSTREO01 probe for CARD-FISH, labeled with Alexa488, and after, viruses were hybridized with the 11 viral probes designed for Ostreococcus viruses labeled with Alexa594 (Castillo et al., 2020). Although the probes were originally designed for the Ostreococcus tauri virus 5 (OtV5), the genome region targeted by the probes is highly similar for most Ostreococcus virus sequenced to date (Fig. S1A, Table S1). Thus, our probes putatively target most Ostreococcus viruses. In order to further test this, we applied VirusFISH to a different Ostreococcus-virus system: Ostreococcus mediterraneus strain MA3 with the virus OmV2 (Yau et al., 2020), and compared the VirusFISH visualization to previous results obtained with the $O$. tauri - 
OtV5 system (see supplementary methods and Fig. S1B,C). This confirmed that the probes hybridize to other Ostreococcus viruses.

Ostreococcus cells were observed by epifluorescence microscopy under blue light (475/30 nm excitation, 527/54 BP emission, and FT 495 beam splitter) and Ostreococcus viruses under orange light (585/35 nm excitation, 615 LP emission, and FT 570 beam splitter). All pictures were taken using the same intensities and exposure times (300 ms for the blue light and $1 \mathrm{~s}$ for the orange light). For each sample, 4 random transects, between 6 and $10 \mathrm{~mm}$ each, were performed to visualize and count infected and noninfected Ostreococcus. The number of inspected Ostreococcus cells ranged from nondetected to 20 cells per sample. A total of 57 samples were evaluated with VirusFISH.

\section{Identification of Ostreococcus spp. and Ostreococcus virus sequences in metatranscriptomes}

Metatranscriptomic information from the continental shelf station (E2) during 2011 and 2012 was retrieved from (Alonso-Sáez et al., 2020). Metatranscriptomic reads, previously quality trimmed and cleaned of rRNA sequences, were screened for Ostreococcus spp. (OS) and Ostreococcus virus (OV) sequences. First, a BLASTn database was constructed of the four Ostreococcus species nuclear genomes (O. tauri RCC4221, O. lucimarinus CCE9901, Osterococcus sp. RCC809 and O. mediterraneus RCC2590) and the 13 complete Ostreococcus spp. virus genomes sequenced to date. The Genbank accession numbers of the genomes used were as follows. O. tauri: CAID01000001.2CAID01000020.2, ～O. lucimarinus: CP000581.1-CP000601.1， O. mediterraneus: WMKK01000001.1-WMKK01000022.1, OtV1: FN386611.1, OtV2: FN600414.1, OtV5: EU304328.2, OtV6: JN225873.1, OlV1: MK514405.1, OlV2: KP874736.1, OlV3: 
HQ633060.1, OlV4: JF974316.1, OlV5: HQ632827.1, OlV6: HQ633059.1, OlV7: MK514406.1 and OmV1: KP874735.1 and OmV2 (MN688676). The Ostreococcus sp. RCC809 genome was obtained from the JGI Genome portal (https://genome.jgi.doe.gov/portal/ - accessed 28 February 2014). Second, the metatranscriptomic reads were queried against OS and OV genomes by BLASTn (BLAST 2.2.26+), accepting high scoring pairs with e-value $<1 \mathrm{e}^{-}-5$, identity $>75 \%$ and query coverage $>75 \%$. This nucleotide identity cut-off was chosen as it corresponds to the average nucleotide identity between Ostreococcus spp. (O. tauri and O. lucimarinus), as well as between representatives of Ostreococcus virus clades (OtV5 and OtV6), and thereby avoids retrieving reads that originate from related Mamiellophyceae and prasinoviruses. Average nucleotide identities were calculated with the ANI server (http://enve-omics.ce.gatech.edu/ani). Third, metatranscriptomic reads matching OS and OV genomes from each sample were counted, assigned to the species corresponding to the top BLASTn hit. Finally, OS and OV read counts were expressed as counts per 100,000 reads to adjust for variation in per sample sequencing depth.

\section{Transcriptome coverage of Ostreococcus viruses}

To determine which regions of the viral genomes were expressed, metatranscriptomic reads were aligned to available genomes of viruses infecting Ostreococcus using BWA version 7.17 (Li and Durbin, 2009) with default parameters. The resulting alignments were visualized in IGV version 2.5.3 (Robinson et al., 2011) as a Sashimi Plot. Read counts for the predicted coding sequences (CDS) were counted for each genome using the HTSeq version 0.9.1 (Anders et al., 2015) package with the function htseq-count (default parameters except for -t CDS -i = "locus_tag”) taking the alignment files from 
BWA and the predicted CDS from the published GenBank genome annotations as input files.

\section{Statistical analysis}

Correlation analyses were performed using Pearson correlation. All statistical analyses were accomplished with the JMP 9.0.1 (JMP®, Version 9.0.1. SAS Institute Inc., Cary, NC, 1989-2019.) or R 3.5.3 (R Development Core Team, 2016) software.

\section{RESULTS}

\section{Environmental setting}

In surface waters, the temperature ranged from $\sim 12.3^{\circ} \mathrm{C}$ in winter to $\sim 21.2^{\circ} \mathrm{C}$ in summer during 2011 and 2012 (Fig. S2). In contrast, salinity was rather constant throughout the year at an average of 35.7, with occasionally lower values in winter and autumn, and a marked decline in April 2012 at all the three stations ( 35, Fig. S2). Chlorophyll $a$ (Chl a) concentration at the surface in 2011 and 2012 peaked during spring and autumn reaching values of $\sim 1 \mu \mathrm{g} \mathrm{L}-1$ at the three stations, and also in summer at station E1. At 50 m depth, there was much less variation than at the surface in temperature (range: 12-18.3 ${ }^{\circ} \mathrm{C}$ ) and salinity (range: 35.6-35.8). In contrast, Chl $a$ showed three peaks: in June at E2 in 2011, in May at E3 in 2012, and in late summer at both stations in 2012 (Fig. S2). Between June and November, a subsurface chlorophyll maximum (DCM) developed at around $40-50 \mathrm{~m}$ at the two shelf stations. As expected, nitrate $\left(\mathrm{NO}_{3}\right)$ and phosphate $\left(\mathrm{PO}_{4}\right)$ concentrations were in general lower at the surface than at the DCM for all stations and reached their maximum values during winter at both depths (Table S2).

Abundance of autotrophic picoeukaryotes (PE) was in general two-fold higher in surface waters than at $50 \mathrm{~m}$ depth (Fig. 2). At the surface, PE reached maximum abundances in 
April and November for all three stations, with E1 also showing high values in summer, coincident with the peak in Chl $a$. At $50 \mathrm{~m}$ depth, PE were almost absent during winter but from late spring to autumn their abundance ranged between 5,000 and 20,000 cells $\mathrm{mL}^{-1}$ (Fig. 2).

\section{Dynamics of Ostreococcus and its viral infection during an annual cycle}

Using VirusFISH we tracked the abundance of Ostreococcus and virally infected Ostreococcus cells during 2012. Ostreococcus cells were counted as infected when the red fluorescence of the VirusFISH probe (see methods section) overlapped with the green signal of the Ostreococcus CARD-FISH probe (Fig. 3). The contribution of Ostreococcus to the picoeukaryotic assemblages over the seasonal cycle ranged from non-detectable to 20.8\% in surface waters, averaging 2.6\% (180 Ostreococcus $\mathrm{mL}^{-1}$ ), and from nondetectable to $8.9 \%$ at $50 \mathrm{~m}$ depth, averaging $1.7 \%$ (184 Ostreococcus $\mathrm{mL}^{-1}$ ) (Table S3). In surface waters at station E1, Ostreococcus abundances started to increase in late spring and reached the highest values in summer (1,226 Ostreococcus $\mathrm{mL}^{-1}$, Fig. 4). At the midshelf (E2) Ostreococcus cells displayed two relative maxima in July and NovemberDecember (508 - 361 Ostreococcus $\mathrm{mL}^{-1}$, Fig. 4), and at the shelf station (E3) we obtained similar results as in E2, with two relative maxima in July and November (578 342 Ostreococcus $\mathrm{mL}^{-1}$, Fig. 4). Remarkably, Ostreococcus cells could not be detected in August at the two stations more distant from shore (E2 and E3), whereas they showed maximal abundances at the coastal station E1 (Fig. 4A). At $50 \mathrm{~m}$ depth, Ostreococcus cells were also mainly found in summer and autumn, with the exception of October (Fig. 4B). Although Ostreococcus abundances reached higher values in surface waters than at $50 \mathrm{~m}$ depth, year-round average values were similar for both depths and among stations (i.e. E1 surface: $208.3 \pm 105$ cells $\mathrm{mL}^{-1}$; E2 surface: $127.9 \pm 53.6$ cells $\mathrm{mL}^{-1}$, E2 $50 \mathrm{~m}$ : 
151.1 \pm 38.3 cells $\mathrm{mL}^{-1}$; E3 surface: $121 \pm 54.1$ cells $\mathrm{mL}^{-1}$, E3 $50 \mathrm{~m}$ : $133.7 \pm 54.8$ cells mL$\left.{ }^{1}\right)$.

In surface waters of E1, viral infection was observed in June, July, September, November and December, representing from 11 to $60 \%$ of the cells (22 - 78 infected Ostreococcus $\mathrm{mL}^{-1}$, Fig. 4). In E2, infected cells were visualized in late spring to early summer, representing from 7 to $50 \%$ of the cells (25 - 36 infected Ostreococcus $\mathrm{mL}^{-1}$, Fig. 4). In E3, we could only detect infected cells in November, which accounted for $25 \%$ of the Ostreococcus population (86 infected Ostreococcus $\mathrm{mL}^{-1}$, Fig. 4). Thus, the impact of viruses on Ostreococcus cells in surface waters along the coastal-shelf gradient analyzed here was variable, but infection took place mostly from May to June and from November to December (Fig. 4A, Table 1). Contrary to surface samples, at $50 \mathrm{~m}$ depth no infected cells could be detected at any time (Fig. 4B).

There was a significant positive relationship between the abundance of Ostreococcus and the abundance of autotrophic picoeukaryotes (Pearson correlation analysis. $\mathrm{R}=0.42$, $\mathrm{p}$ value $=0.0016, n=54)$. The number of infected cells was also positively correlated with the abundance of autotrophic picoeukaryotes (Pearson correlation analysis. $\mathrm{R}=0.43$, $\mathrm{p}$ value=0.0013, n=54), but not with Ostreococcus abundance (Table S4).

\section{Detection of Ostreococcus and Ostreococcus viruses in metatranscriptomes}

Both Ostreococcus species (OS) and their viruses (OV) were detected in metatranscriptomic samples collected during 2011 and 2012 at the mid-shelf station (E2), except for May and July 2011, when OV were not detected, coincident with very low abundances of host transcripts (Fig. 5). The relative abundance of OS transcripts displayed a maximum in November, was second highest in April and remained low in the spring and summer months of May and July both in 2011 and 2012 (Fig. 5, upper panel). 
The relative abundance of OV transcripts was more variable between sampling years. The highest values of OV transcripts were observed in April and November, being notably higher in 2011 than in 2012, and the lowest in May and July. The relative abundance of viral transcripts in relation to the abundance of host transcripts was higher in April 2011, pointing to a larger infection event at this sampling time (Fig. 5, lower panel).

Regarding the phylogenetic affiliation of the OS and OV transcripts, we found that the Ostreococcus assemblage maintained the same rank species abundance profile in all samples, with O. lucimarinus as the most transcriptionally active species (51-91\% of Ostreococcus reads), followed by O. tauri (6-47\% of reads), while Ostreococcus sp. RCC809 and O. mediterraneus were minor contributors (both $1-4 \%$ of reads). This pattern was also reflected in the OV transcript pool, with $O$. lucimarinus virus transcripts dominating, followed by O. tauri viruses. O. mediterraneus viruses represented a minor fraction of the transcripts, whereas the only known virus infecting Ostreococcus sp. RCC809, OtV2 (Weynberg et al., 2011), was not detected (Fig. 5).

When the percentage of infected cells detected by VirusFISH was compared to the ratio of OV/OS transcripts we obtained consistent results, with samples where the number of infected cells was higher having higher OV/OS ratios (Fig. S3).

\section{Transcriptome coverage of Ostreococcus viruses}

To determine which genomic regions of the Ostreococcus viruses were being transcribed in the samples, all metatranscriptomic reads were aligned to the model Ostreococcus virus strain, OtV5, which is the virus that has received the most extensive molecular characterization (Derelle et al., 2008, 2017; Yau et al., 2016), and other Ostreococcus virus. O. lucimarinus viruses showed approximately twice the percentage of CDS transcribed compared to O. tauri infecting viruses ( 20\% compared to $\sim 9 \%$, Table S5). 
The pattern of transcription between Ostreococcus viruses was comparable (Fig. S4), and despite the low read coverage ( 100 reads, Table S5) due to the low sequencing depth of the metatranscriptomes, transcripts were distributed along the viral genome length. This indicates that the entire viral genomes were transcribed in situ. Furthermore, genes likely involved in transcription, DNA replication and capsid assembly were expressed, suggesting that Ostreococcus viruses were captured during active infection of their host cells. The most highly expressed gene was the major capsid protein, further suggesting the viruses were sampled during lytic replication.

\section{DISCUSSION}

Our results showed generally low abundances of Ostreococcus over the seasonal cycle, although this genus occasionally represented up to $\sim 20 \%$ of total picoeukaryotic cells (Table S3). This is in agreement with previous results showing that Ostreococcus in coastal and shelf sea waters present $<5 \cdot 10^{3}$ cells $\mathrm{mL}^{-1}$ at the surface and DCM (Zhu et al., 2005; Countway and Caron, 2006; Cardol et al., 2008), unlike in lagoons such as the Thau Lagoon (NW Mediterranean, France), where O. tauri can dominate the phytoplankton assemblage based on flow cytometric signatures (Chrétiennot-Dinet et al., 1995; Vaquer et al., 1996). Despite Ostreococcus can produce sporadic blooms, increasing two orders of magnitude over its basal concentration and accounting for up to $70 \%$ of the total picoeukaryotic community (O’Kelly et al., 2003; Countway and Caron, 2006), we did not observe any of these blooms over our seasonal cycle. With a few exceptions, the highest contribution of Ostreococcus to the picoeukaryotic assemblage occurred in summer (Table S3). This might indicate that this tiny picoeukaryote is better adapted than other members of the picoeukaryotic assemblage to grow under low inorganic nutrient conditions that characterize the period from April-May to October in these coastal waters. 
Indeed, this period is usually characterized by maxima in picophytoplankton biomass (Calvo-Díaz and Morán, 2006; Calvo-Díaz et al., 2008).

Ostreococcus viral infection dynamics was variable throughout the year, with the percentage of infected cells ranging from non-detected to $60 \%$. This supports the view that viruses may have an impact in controlling the abundance of Ostreoccocus cells, as it has been suggested in other field studies where infected Ostreococcus cells were visualized with TEM (O’Kelly et al., 2003). Most Ostreococcus viruses isolated to date have fast infection cycles in culture, with clearance of the culture observed usually within two days (Derelle et al., 2008; Zimmerman et al., 2019; Castillo et al., 2020). However, coexistence between the host and the virus for longer periods of time has also been observed (Thomas et al., 2011; Yau et al., 2020). In the bloom-forming algae Emiliania huxleyi it was recently shown that virulent virus may prevalently display temperate infection dynamics in nature, switching only to a lethal infection when the physiology of the cells become compromised due to high cell densities (Knowles et al., 2020). Nonetheless, this may be different in species that show predominantly low abundances, like Ostreococcus. Moreover, our monthly sampling frequency was likely not enough to detect episodes of boom and bust in the Ostreococcus populations or to quantify the role of viruses in controlling their dynamics. Similarly, Johannessen et al. (2017) reported that Haptophyte and virus community composition and diversity varied substantially during an annual cycle without any clear pattern of covariance. In a study conducted over three years, both Micromonas pusilla and its viruses were shown to fluctuate widely on smaller time scales (i.e., weekly sampling, Zingone et al. 1999). Indeed, a tipping point during infection dynamics after which the infection rapidly propagates has been reported in both lab experiments and in natural populations (Zimmerman et al., 2019; Castillo et al., 2020; Vincent et al., 2021), as well as strong diel cycle infection dynamics (Aylward et al., 
2017; Chen and Zeng, 2020). Altogether, these observations suggest that high frequency samplings (i.e. over hourly to daily scales) should be carried out to fully apprehend viruseukaryote interactions in nature. In any case, our work is the first approximation that directly assessed the impact of viruses on a picoeukaryotic population under non-bloom conditions in nature. The fact that Ostreococcus were found in very different abundance levels across the spatial and temporal gradient studied here was important to test the performance of VirusFISH on this model microorganism.

The use of a general Ostreococcus CARD-FISH probe does not allow to distinguish between species. However, metatranscriptomic data from surface waters unveiled that the dominating species was O. lucimarinus. A previous study has shown that this species inhabits waters from the surface to the DCM (Rodríguez et al., 2005) and it is the most widely distributed, whereas $O$. tauri and $O$. mediterraneus are mostly restricted to the surface layer of coastal waters and lagoons (Rodríguez et al., 2005; Tragin and Vaulot, 2019). Thus, it is likely that most Ostreococcus cells found in our samples belonged to O. lucimarinus.

The metatranscriptomic data also indicated that $O$. lucimarinus coexisted with several viruses infecting this species. Ostreococcus viral transcriptional activity was higher in 2011 than in 2012, when we did the VirusFISH analyses. However, even in 2011 their transcriptional activity was low relative to that of the hosts suggesting that the impact of viruses on the Ostreoccocus populations was only moderate (Fig. 5). High Ostreococcus viral transcriptional activity relative to that of their putative hosts has been shown based on metatranscriptomics in the Baltic Sea (Zeigler Allen et al., 2017). Therefore, we may have missed large infection events due to our monthly sampling frequency. A recent transcriptomic study on an infection of Prasinovirus upon Ostreococcus has shown that the viral attack occurs mostly at night (Derelle et al., 2017), 
which may also explain the low viral transcriptional activity detected in our samples, that were taken around noon. Finally, other factors that may contribute to this relatively low viral activity are the coexistence of distinct transcriptional states during infection dynamics (Vincent et al., 2021), and the co-occurrence of susceptible and resistant host phenotypes (Yau et al., 2020) to the array of Ostreococcus viruses present at each sampling time-point (Fig. 5). A combination of metatranscriptomics with VirusFISH analyses performed with higher sampling frequency should help gain a clearer insight into the virus-host dynamics of natural populations of Ostreococcus.

It is important to note that it is possible that the VirusFISH probes used were not able to detect the full diversity of virus infecting the natural populations of Ostreococcus. This could be the reason for the lack of detection of infection at $50 \mathrm{~m}$ depth. However, according to Allers et al. (2013), a single probe is enough to visually detect one virus, with the detection efficiency increasing with the number of viral probes used, and most of the Ostreococcus virus sequenced to date are highly similar in at least 8 of the probes used (Table S1). The fact that the VirusFISH results were consistent with the metatranscriptomic data suggests that a broad range of Ostreococcus virus can indeed be hybridized by the probes, further supporting the use of these probes to monitor natural infection dynamics of this important picoeukaryote. VirusFISH can detect both early and late infection stages, as in our experiments with cultures we were able to quantify infected Ostreococcus cells when viral production was still negligible (Castillo et al., 2020). Thus, we believe that the reason we did not detect any infected cells at $50 \mathrm{~m}$ is because the level of infection was likely lower than in the surface, and the volume of sample filtered was probably too small for the low abundance of Ostreococcus cells. In fact, this may also be the reason why we did not detect infection at some of the surface samples over the seasonal cycle. 
In conclusion, we show that VirusFISH has strong potential to follow the dynamics of hosts and their infecting viruses in nature. It requires the previous knowledge of the viral genome, and preferably also the host genome to design the adequate probes (i.e. probes that do not target regions of the host genome that are similar to the virus), as well as the viral DNA material to use it as template to synthetize the probes. Having both elements, this approach can be easily implemented with any genome-sequenced virus-host system available in culture. Furthermore, VirusFISH can also be used to unveil unknown eukaryotic hosts of abundant viruses detected in metaviromes, by using that environmental DNA to synthetize the viral probes. Hence, VirusFISH opens avenues in viral ecology to tackle the role of viruses in controlling the abundance of key players in marine microbial communities, allowing to visually quantify the impact on specific host populations.

\section{ACKNOWLEDGMENTS}

This work was supported by the Spanish projects MEFISTO (CTM2013-43767-P, MINECO) and ALLFLAGS (CTM2016-75083-R, MINECO). YMC was supported by a FPI Spanish fellowship (BES-2014-067849), SY was supported by a Juan de la Cierva fellowship (IJCI-2017-34245) and LAS was supported by a Juan de la Cierva and Ramon y Cajal contract (RYC-2012-11404). MS was supported by a Viera y Clavijo contract funded by the ACIISI and the ULPGC. NAG was supported by Basque Government's PhD-program fellowship. The authors declare that there is no conflict of interest regarding the publication of this article. 


\section{REFERENCES}

Allers, E., Moraru, C., Duhaime, M.B., Beneze, E., Solonenko, N., Barrero-Canosa, J., et al. (2013) Single-cell and population level viral infection dynamics revealed by phageFISH, a method to visualize intracellular and free viruses. Environ Microbiol 15: 2306-2318.

Alonso-Sáez, L., Morán, X.A.G., and Clokie, M.R. (2018) Low activity of lytic pelagiphages in coastal marine waters. ISME J 12: 2100-2102.

Alonso-Sáez, L., Morán, X.A.G., and González, J.M. (2020) Transcriptional patterns of biogeochemically relevant marker genes by temperate marine bacteria. Front Microbiol 11: 465.

Anders, S., Pyl, P.T., and Huber, W. (2015) HTSeq--a Python framework to work with high-throughput sequencing data. Bioinformatics 31: 166-169.

Arandia-Gorostidi, N., Huete-Stauffer, T.M., Alonso-Sáez, L., and G. Morán, X.A. (2017) Testing the metabolic theory of ecology with marine bacteria: different temperature sensitivity of major phylogenetic groups during the spring phytoplankton bloom. Environ Microbiol 19: 4493-4505.

Aylward, F.O., Boeuf, D., Mende, D.R., Wood-Charlson, E.M., Vislova, A., Eppley, J.M., et al. (2017) Diel cycling and long-term persistence of viruses in the ocean's euphotic zone. Proc Natl Acad Sci U S A 114: 11446-11451.

Barrero-Canosa, J., Moraru, C., Zeugner, L., Fuchs, B.M., and Amann, R. (2017) Direct-geneFISH: a simplified protocol for the simultaneous detection and quantification of genes and rRNA in microorganisms. Environ Microbiol 19: 7082.

Baudoux, A.-C., Lebredonchel, H., Dehmer, H., Latimier, M., Edern, R., RigautJalabert, F., et al. (2015) Interplay between the genetic clades of Micromonas and their viruses in the Western English Channel. Environ Microbiol Rep 7: 765-773.

Bellec, L., Grimsley, N., Derelle, E., Moreau, H., and Desdevises, Y. (2010) Abundance, spatial distribution and genetic diversity of Ostreococcus tauri viruses in two different environments. Environ Microbiol Rep 2: 313-321.

Calvo-Díaz, A. and Morán, X. (2006) Seasonal dynamics of picoplankton in shelf waters of the southern Bay of Biscay. Aquat Microb Ecol 42: 159-174.

Calvo-Díaz, A., Morán, X.A.G., and Suárez, L.Á. (2008) Seasonality of picophytoplankton chlorophyll $a$ and biomass in the central Cantabrian Sea, southern Bay of Biscay. J Mar Syst 72: 271-281.

Cardol, P., Bailleul, B., Rappaport, F., Derelle, E., Beal, D., Breyton, C., et al. (2008) An original adaptation of photosynthesis in the marine green alga Ostreococcus. Proc Natl Acad Sci 105: 7881-7886.

Castillo, Y.M., Mangot, J., Benites, L.F., Logares, R., Kuronishi, M., Ogata, H., et al. (2019) Assessing the viral content of uncultured picoeukaryotes in the globalocean by single cell genomics. Mol Ecol 28: 4272-4289.

Castillo, Y.M., Sebastián, M., Forn, I., Grimsley, N., Yau, S., Moraru, C., and Vaqué, D. (2020) Visualization of viral infection dynamics in a unicellular eukaryote and quantification of viral production using virus fluorescence in situ hybridization. Front Microbiol 11: 1559.

Chen, F. and Suttle, C.A. (1995) Amplification of DNA polymerase gene fragments from viruses infecting microalgae. Appl Environ Microbiol 61: 1274-8.

Chen, Y. and Zeng, Q. (2020) Temporal transcriptional patterns of cyanophage genes suggest synchronized infection of cyanobacteria in the oceans. Microbiome 8: 68 .

Chrétiennot-Dinet, M.J., Courties, C., Vaquer, A., Neveux, J., Claustre, H., Lautier, J., 
and Machado, M.C. (1995) A new marine picoeucaryote: Ostreococcus tauri gen. et sp. nov. (Chlorophyta, Prasinophyceae). Phycologia 34: 285-292.

Cottrell, M. and Suttle, C. (1995) Genetic diversity of algal viruses which lyse the photosynthetic picoflagellate Micromonas pusilla (Prasinophyceae). Appl Environ Microbiol 61: 3088-91.

Cottrell, M. and Suttle, C. (1991) Wide-spread occurrence and clonal variation in viruses which cause lysis of a cosmopolitan, eukaryotic marine phytoplankter Micromonas pusilla. Mar Ecol Prog Ser 78: 1-9.

Countway, P.D. and Caron, D.A. (2006) Abundance and distribution of Ostreococcus sp. in the San Pedro Channel, California, as revealed by quantitative PCR. Appl Environ Microbiol 72: 2496-506.

Courties, C., Vaquer, A., Troussellier, M., Lautier, J., Chrétiennot-Dinet, M.J., Neveux, J., et al. (1994) Smallest eukaryotic organism. Nature 370: 255-255.

Demir-Hilton, E., Sudek, S., Cuvelier, M.L., Gentemann, C.L., Zehr, J.P., and Worden, A.Z. (2011) Global distribution patterns of distinct clades of the photosynthetic picoeukaryote Ostreococcus. ISME J 5: 1095-1107.

Derelle, E., Ferraz, C., Escande, M.-L., Eychenié, S., Cooke, R., Piganeau, G., et al. (2008) Life-cycle and genome of OtV5, a large DNA virus of the pelagic marine unicellular green alga Ostreococcus tauri. PLoS One 3: e2250.

Derelle, E., Ferraz, C., Rombauts, S., Rouze, P., Worden, A.Z., Robbens, S., et al. (2006) Genome analysis of the smallest free-living eukaryote Ostreococcus tauri unveils many unique features. Proc Natl Acad Sci 103: 11647-11652.

Derelle, E., Monier, A., Cooke, R., Worden, A.Z., Grimsley, N.H., and Moreau, H. (2015) Diversity of viruses infecting the green microalga Ostreococcus lucimarinus. J Virol 89: 5812-5821.

Derelle, E., Yau, S., Moreau, H., and Grimsley, N.H. (2017) Prasinovirus attack of Ostreococcus is furtive by day but savage by night. $J$ Virol 92: JVI.01703-17.

Gran-Stadniczeñko, S., Krabberød, A.K., Sandaa, R.-A., Yau, S., Egge, E., and Edvardsen, B. (2019) Seasonal dynamics of algae-infecting viruses and their inferred interactions with protists. Viruses 11: 1043.

Hochstein, R.A., Amenabar, M.J., Munson-McGee, J.H., Boyd, E.S., and Young, M.J. (2016) Acidianus tailed spindle virus: new archaeal large tailed spindle virus discovered by culture-independent methods. J Virol 90: 3458-3468.

JMP®, Version 9.0.1. SAS Institute Inc., Cary, NC, 1989-2019.

Johannessen, T., Larsen, A., Bratbak, G., Pagarete, A., Edvardsen, B., Egge, E., and Sandaa, R.-A. (2017) Seasonal dynamics of Haptophytes and dsDNA algal viruses suggest complex virus-host relationship. Viruses 9: 84.

Knowles, B., Bonachela, J.A., Behrenfeld, M.J., Bondoc, K.G., Cael, B.B., Carlson, C.A., et al. (2020) Temperate infection in a virus-host system previously known for virulent dynamics. Nat Commun 11: 4626.

Laber, C.P., Hunter, J.E., Carvalho, F., Collins, J.R., Hunter, E.J., Schieler, B.M., et al. (2018) Coccolithovirus facilitation of carbon export in the North Atlantic. Nat Microbiol 3: 537-547.

Larsen, J.B., Larsen, A., Bratbak, G., and Sandaa, R.-A. (2008) Phylogenetic analysis of members of the Phycodnaviridae virus family, using amplified fragments of the major capsid protein gene. Appl Environ Microbiol 74: 3048-3057.

Lehahn, Y., Koren, I., Schatz, D., Frada, M., Sheyn, U., Boss, E., et al. (2014) Decoupling physical from biological processes to assess the impact of viruses on a mesoscale algal bloom. Curr Biol 24: 2041-2046.

Li, H. and Durbin, R. (2009) Fast and accurate short read alignment with Burrows- 
Wheeler transform. Bioinformatics 25: 1754-1760.

Lim, S.W., Lance, S.T., Stedman, K.M., and Abate, A.R. (2017) PCR-activated cell sorting as a general, cultivation-free method for high-throughput identification and enrichment of virus hosts. J Virol Methods 242: 14-21.

Lima-Mendez, G., Faust, K., Henry, N., Decelle, J., Colin, S., Carcillo, F., et al. (2015) Ocean plankton. Determinants of community structure in the global plankton interactome. Science 348: 1262073.

Mizuno, C.M., Rodriguez-Valera, F., Kimes, N.E., and Ghai, R. (2013) Expanding the marine virosphere using metagenomics. PLoS Genet 9: e1003987.

Monier, A., Chambouvet, A., Milner, D.S., Attah, V., Terrado, R., Lovejoy, C., et al. (2017) Host-derived viral transporter protein for nitrogen uptake in infected marine phytoplankton. Proc Natl Acad Sci 114: E7489-E7498.

Nishimura, Y., Watai, H., Honda, T., Mihara, T., Omae, K., Roux, S., et al. (2017) Environmental viral genomes shed new light on virus-host interactions in the ocean. mSphere 2: e00359-16.

Not, F., Latasa, M., Marie, D., Cariou, T., Vaulot, D., and Simon, N. (2004) A single species, Micromonas pusilla (Prasinophyceae), dominates the eukaryotic picoplankton in the Western English Channel. Appl Environ Microbiol 70: 4064 72.

O’Kelly, C.J., Sieracki, M.E., Thier, E.C., and Hobson, I.C. (2003) A transient bloom of Ostreococcus (Chlorophyta, Prasinophyceae) in West Neck Bay, Long Island, New York. J Phycol 39: 850-854.

R Development Core Team (2016) R: a language and environment for statistical computing.

Rahlff, J., Turzynski, V., Esser, S., Monsees, I., Bornemann, T., Figueroa-Gonzalez, P.A., et al. (2020) Genome-informed microscopy reveals infections of uncultivated carbon-fixing archaea by lytic viruses in Earth's crust. bioRxiv 2020.07.22.215848.

Robinson, J.T., Thorvaldsdóttir, H., Winckler, W., Guttman, M., Lander, E.S., Getz, G., and Mesirov, J.P. (2011) Integrative genomics viewer. Nat Biotechnol 29: 24-26.

Rodríguez, F., Derelle, E., Guillou, L., Le Gall, F., Vaulot, D., and Moreau, H. (2005) Ecotype diversity in the marine picoeukaryote Ostreococcus (Chlorophyta, Prasinophyceae). Environ Microbiol 7: 853-859.

Roux, S., Chan, L.-K., Egan, R., Malmstrom, R.R., McMahon, K.D., and Sullivan, M.B. (2017) Ecogenomics of virophages and their giant virus hosts assessed through time series metagenomics. Nat Commun 8: 858.

Roux, S., Hawley, A.K., Beltran, M.T., Scofeld, M., Schwientek, P., Stepanauskas, R., et al. (2014) Ecology and evolution of viruses infecting uncultivated SUP05 bacteria as revealed by single-cell- and meta-genomics. Elife 2014:

Sanchez, F., Geffroy, S., Norest, M., Yau, S., Moreau, H., and Grimsley, N. (2019) Simplified transformation of Ostreococcus tauri using polyethylene glycol. Genes (Basel) 10: 399.

Sheyn, U., Rosenwasser, S., Lehahn, Y., Barak-Gavish, N., Rotkopf, R., Bidle, K.D., et al. (2018) Expression profiling of host and virus during a coccolithophore bloom provides insights into the role of viral infection in promoting carbon export. ISME J 12: 704-713.

Suttle, C.A. (2000) Ecological, evolutionary, and geochemical consequences of viral infection of cyanobacteria and eukaryotic algae. In Viral Ecology. Elsevier, pp. 247-296.

Thomas, R., Grimsley, N., Escande, M., Subirana, L., Derelle, E., and Moreau, H. (2011) Acquisition and maintenance of resistance to viruses in eukaryotic 
phytoplankton populations. Environ Microbiol 13: 1412-1420.

Tragin, M. and Vaulot, D. (2019) Novel diversity within marine Mamiellophyceae (Chlorophyta) unveiled by metabarcoding. Sci Rep 9: 5190.

Vaquer, A., Troussellier, M., Courties, C., and Bibent, B. (1996) Standing stock and dynamics of picophytoplankton in the Thau Lagoon (northwest Mediterranean coast). Limnol Oceanogr 41: 1821-1828.

Vincent, F., Sheyn, U., Porat, Z., Schatz, D., and Vardi, A. (2021) Visualizing active viral infection reveals diverse cell fates in synchronized algal bloom demise. Proc Natl Acad Sci 118: e2021586118.

Weynberg, K.D., Allen, M.J., Gilg, I.C., Scanlan, D.J., and Wilson, W.H. (2011) Genome sequence of Ostreococcus tauri virus OtV-2 throws light on the role of picoeukaryote niche separation in the ocean. J Virol 85: 4520-4529.

Wilson, W.H., Tarran, G.A., Schroeder, D., Cox, M., Oke, J., and Malin, G. (2002) Isolation of viruses responsible for the demise of an Emiliania huxleyi bloom in the English Channel. J Mar Biol Assoc United Kingdom 82: 369-377.

Yau, S., Hemon, C., Derelle, E., Moreau, H., Piganeau, G., and Grimsley, N. (2016) A viral immunity chromosome in the marine picoeukaryote, Ostreococcus tauri. PLOS Pathog 12: e1005965.

Yau, S., Krasovec, M., Benites, L.F., Rombauts, S., Groussin, M., Vancaester, E., et al. (2020) Virus-host coexistence in phytoplankton through the genomic lens. Sci Adv 6: eaay2587.

Zeigler Allen, L., McCrow, J.P., Ininbergs, K., Dupont, C.L., Badger, J.H., Hoffman, J.M., et al. (2017) The Baltic Sea virome: diversity and transcriptional activity of DNA and RNA viruses. mSystems 2: e00125-16.

Zhu, F., Massana, R., Not, F., Marie, D., and Vaulot, D. (2005) Mapping of picoeucaryotes in marine ecosystems with quantitative PCR of the 18S rRNA gene. FEMS Microbiol Ecol 52: 79-92.

Zimmerman, A.E., Bachy, C., Ma, X., Roux, S., Jang, H. Bin, Sullivan, M.B., et al. (2019) Closely related viruses of the marine picoeukaryotic alga Ostreococcus lucimarinus exhibit different ecological strategies. Environ Microbiol 21: 21482170.

Zingone, A. (1999) Seasonal dynamics in the abundance of Micromonas pusilla (Prasinophyceae) and its viruses in the Gulf of Naples (Mediterranean Sea). $J$ Plankton Res 21: 2143-2159. 


\section{FIGURES LEGEND}

Figure 1. Location of the sampling stations. Abbreviations: E1: coastal station; E2: midshelf station; E3: shelf station. Samples were taken at 0 and $50 \mathrm{~m}$ depth, except for E1 where the maximum depth was $20 \mathrm{~m}$.

Figure 2. Small autotrophic picoeukaryote abundances for coastal (E1), mid-shelf (E2) and shelf (E3) waters during a two-year period (2011 and 2012). A. Surface and B. $50 \mathrm{~m}$ depth. Note the difference in the $\mathrm{y}$-axis between figures A and B. Note: for July and December 2012 data were not available at $50 \mathrm{~m}$ depth samples.

Figure 3. Micrographs of Ostreococcus cells in natural samples from the Cantabrian Sea. Upper and lower panel: infected Ostreococcus cells (arrow with round head), in which the red signal of the VirusFISH labeled viruses can be easily seen. Middle panel: a healthy non-infected Ostreococcus cell (asterisk) and a lysed Ostreococcus cell showing the viral cloud released from the cell with almost no cytoplasm (arrow with sharp head).

Figure 4. VirusFISH results for Ostreococcus cells abundance and infection by Ostreococcus viruses in 2012. A. Surface, B. 50m depth, in coastal (E1), mid-shelf (E2) and shelf (E3) waters. Note: April data was not available for surface samples.

Figure 5. Relative abundances of Ostreococcus spp. (OS) transcripts (upper plot) and Ostreococcus viruses (OV) transcripts (lower plot) detected in metatranscriptomes from the surface waters at the mid-shelf station (E2). Note the difference in $y$-axis between the graphs. Nov.: November. 


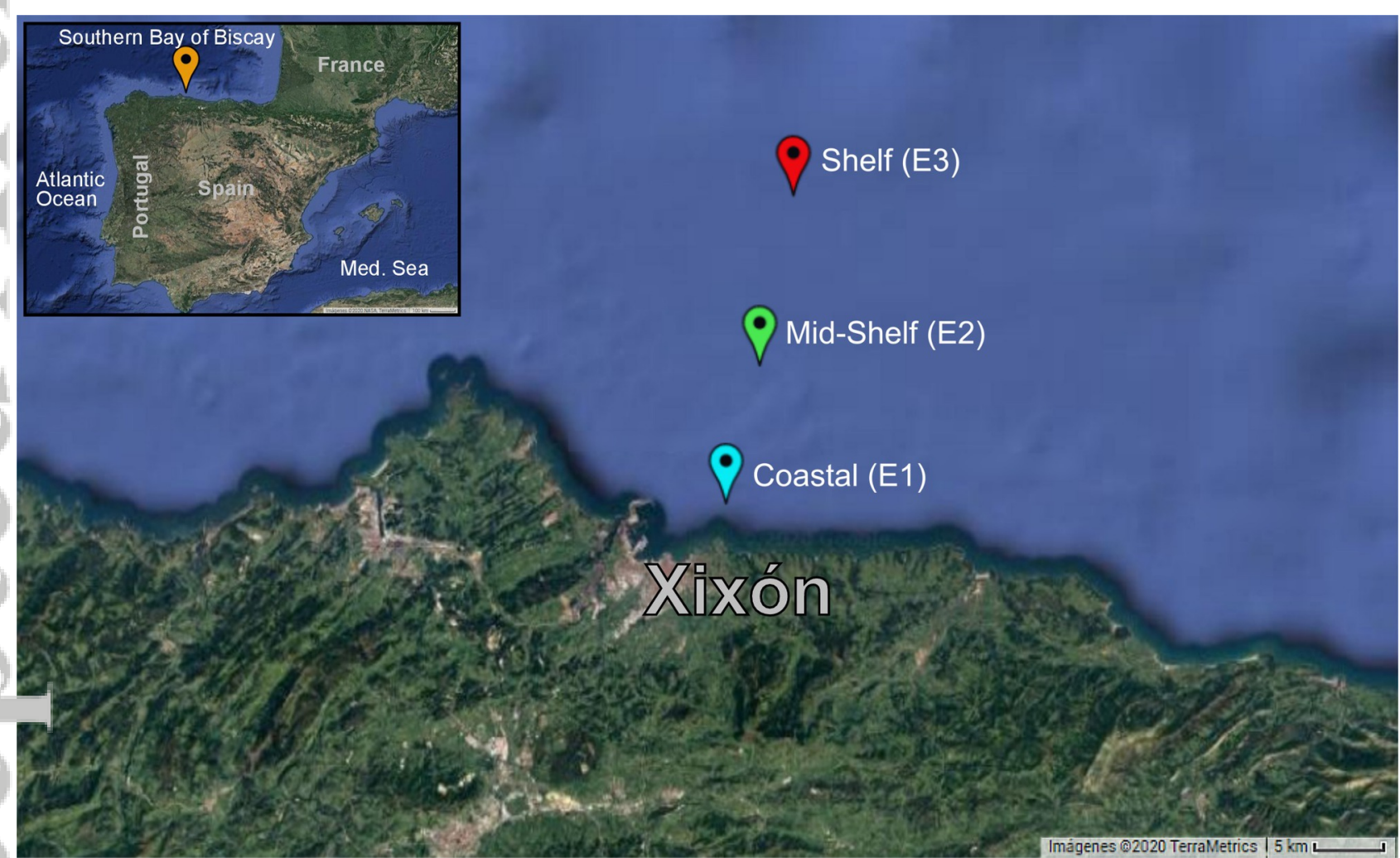

emi_15504_figure_1_castillo_et_al.eps 
A

Surface
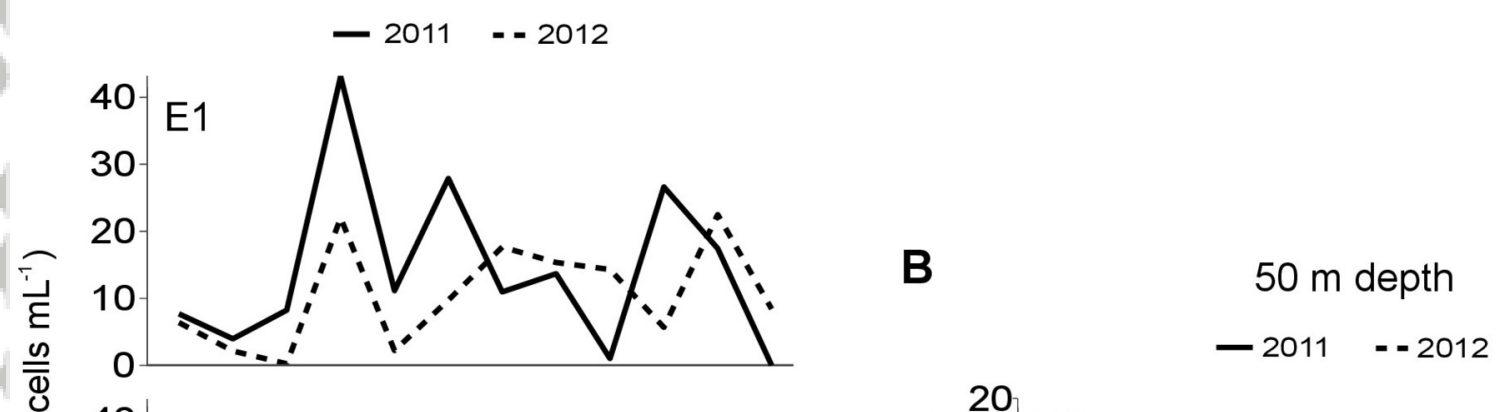

$\stackrel{0}{\circ} \quad 30$ E2

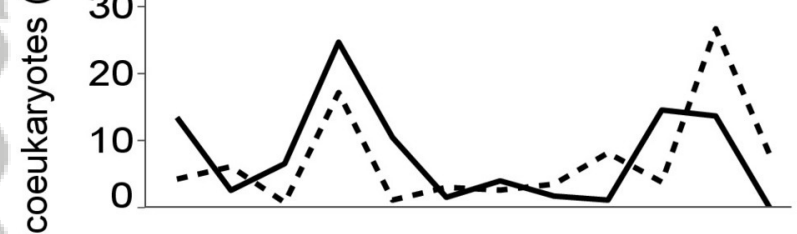

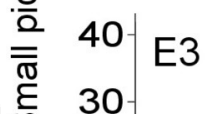

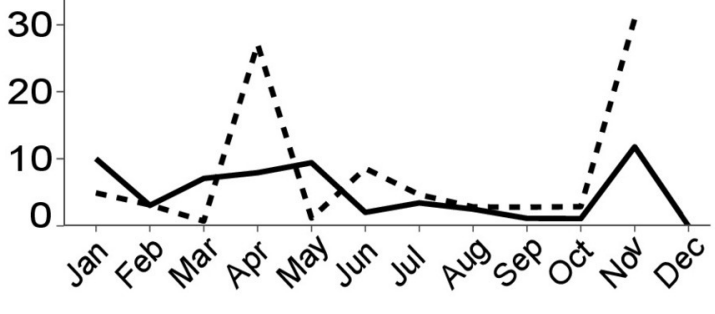

Months
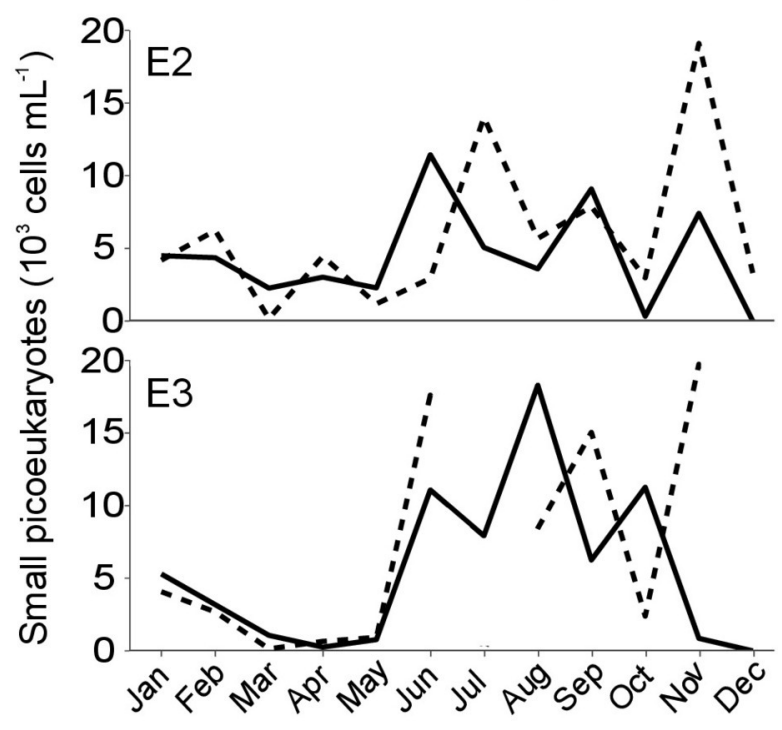

emi_15504_figure_2_castillo_et_al.eps 

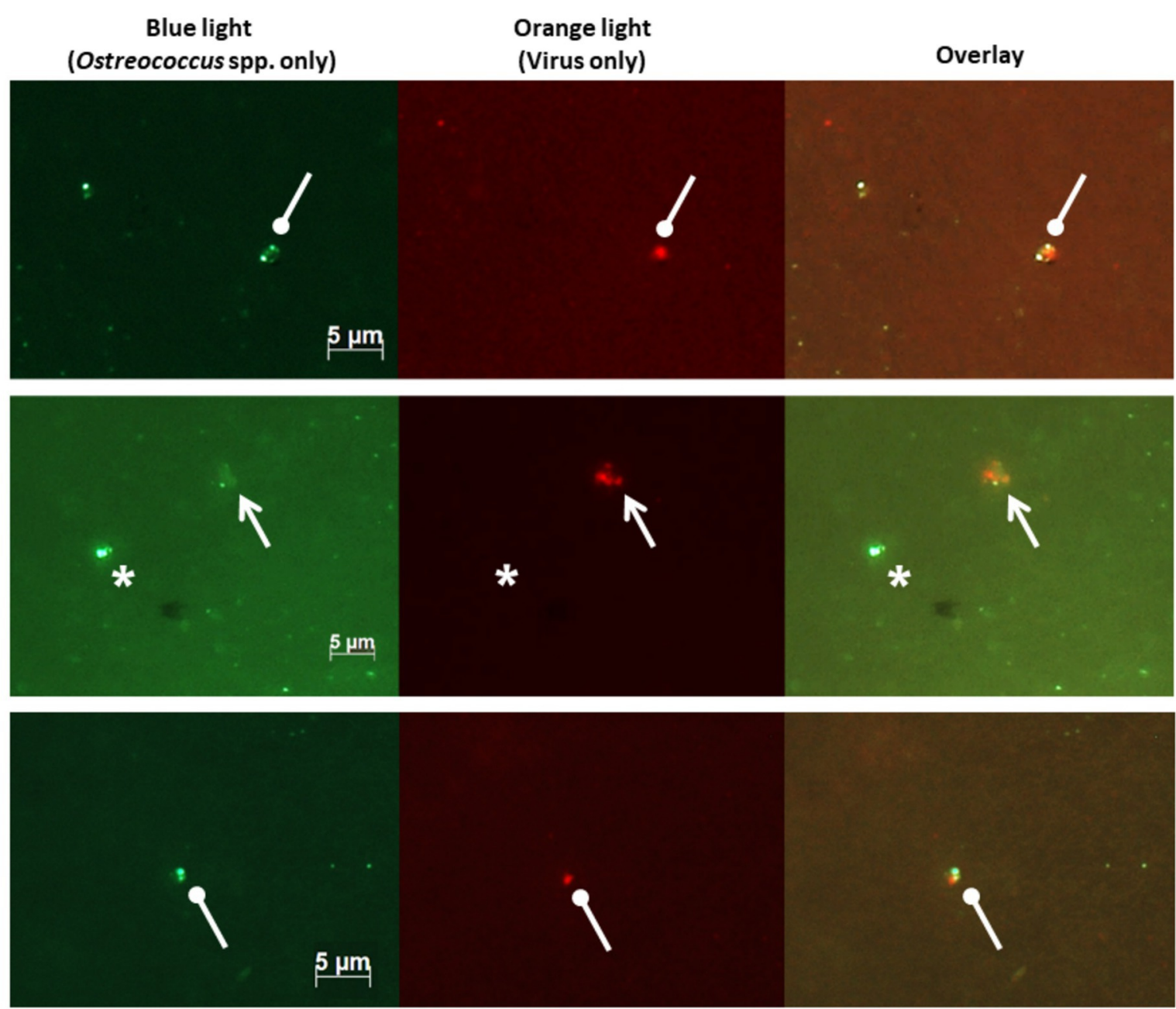

emi_15504_figure_3_castillo_et_al.eps 
A

Surface

Infected Ostreococcus sp.

Not infected Ostreococcus sp.

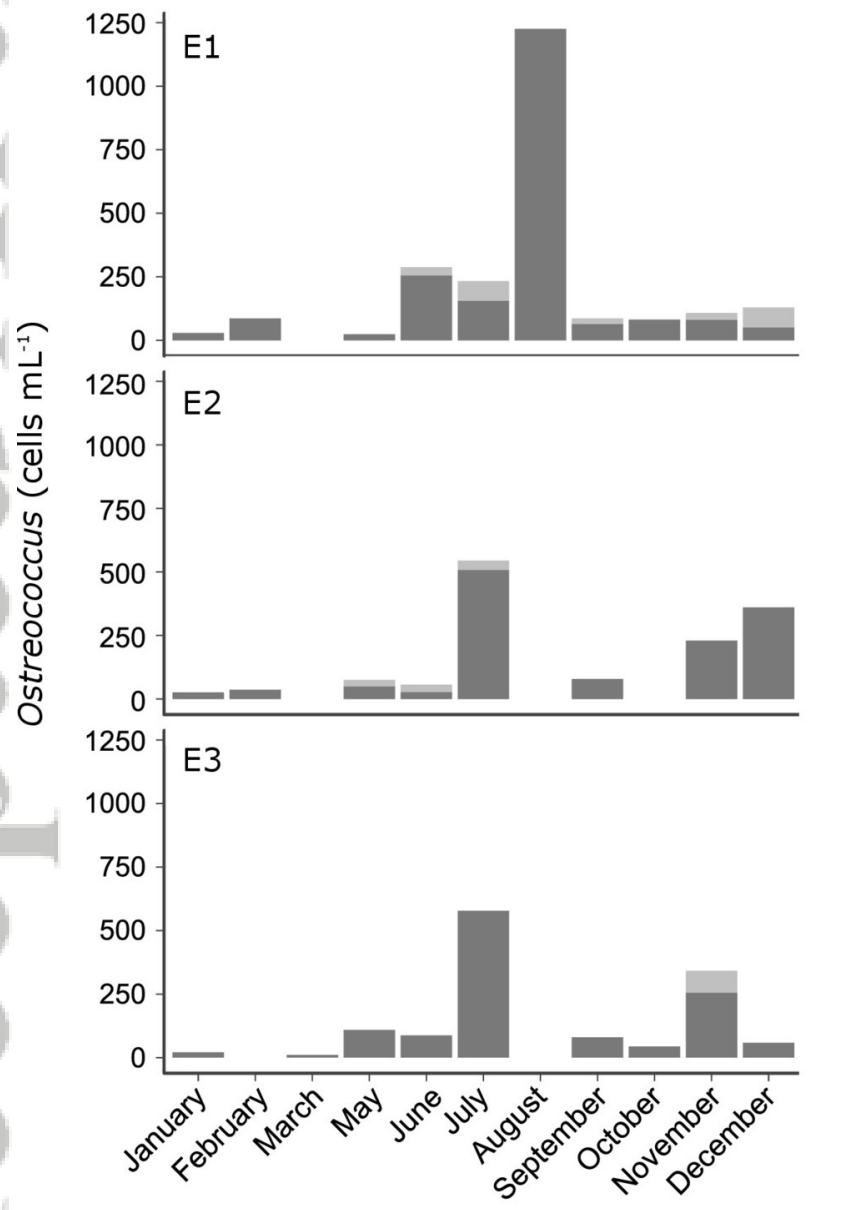

Month

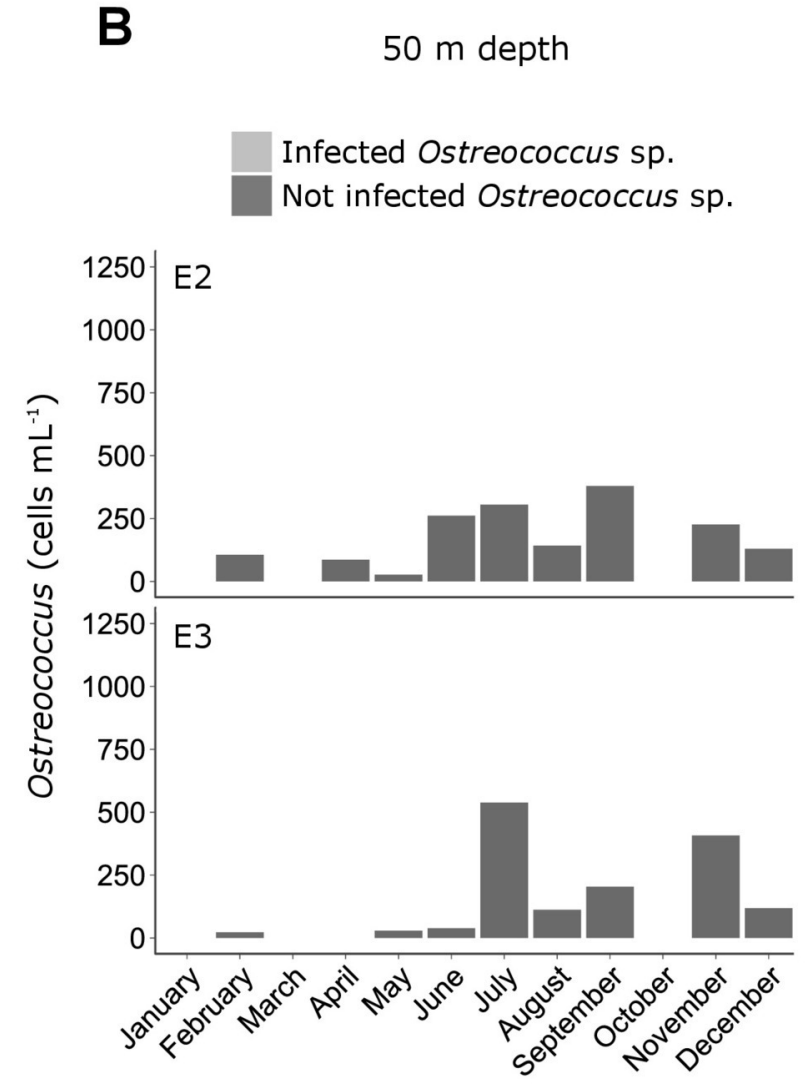

Month

emi_15504_figure_4_castillo_et_al.eps 

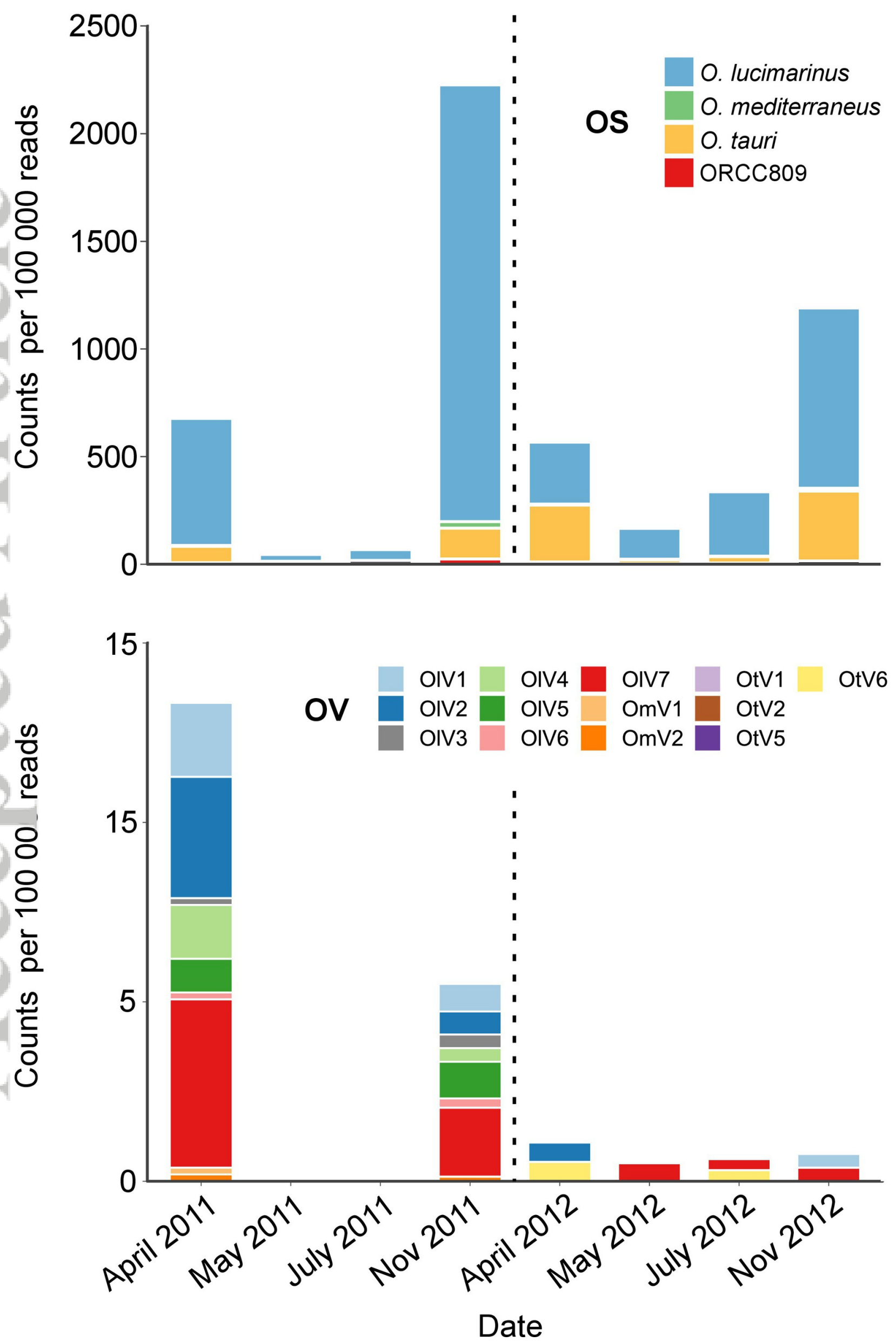

emi_15504_figure_5_castillo_et_al.eps 
Table 1. Impact of viruses on Ostreococcus populations in the coastal (E1), mid-shelf (E2) and shelf (E3) stations. See Figure 1 for the location of the stations. ND: Non-detected; '-': No data available. Color intensity indicates increasing percentage of infected cells.

\begin{tabular}{|c|c|c|c|c|c|c|c|c|c|}
\hline & \multicolumn{3}{|c|}{ E1 } & \multicolumn{3}{|c|}{ E2 } & \multicolumn{3}{|c|}{$\mathbf{E 3}$} \\
\hline & $\begin{array}{c}\text { Total } \\
\text { cells } / \mathbf{m L}\end{array}$ & $\begin{array}{l}\text { Infected } \\
\text { cells } / \mathbf{m L}\end{array}$ & $\begin{array}{c}\% \text { of } \\
\text { infected } \\
\text { cells }\end{array}$ & $\begin{array}{c}\text { Total } \\
\text { cells } / \mathbf{m L}\end{array}$ & $\begin{array}{l}\text { Infected } \\
\text { cells/mL }\end{array}$ & $\begin{array}{c}\% \text { of } \\
\text { infected } \\
\text { cells }\end{array}$ & $\begin{array}{c}\text { Total } \\
\text { cells } / \mathbf{m L}\end{array}$ & $\begin{array}{l}\text { Infected } \\
\text { cells/mL }\end{array}$ & $\begin{array}{c}\% \text { of } \\
\text { infected } \\
\text { cells }\end{array}$ \\
\hline February & 86 & ND & - & 36 & ND & - & ND & ND & - \\
\hline March & ND & ND & - & ND & ND & - & 11 & ND & - \\
\hline April & - & - & - & - & - & - & - & ND & - \\
\hline June & 288 & 32 & 11 & 56 & 28 & 50 & 88 & ND & - \\
\hline July & 233 & 78 & 33 & 544 & 36 & 7 & 578 & ND & - \\
\hline August & 1226 & ND & - & ND & ND & - & ND & ND & - \\
\hline September & 87 & 22 & 25 & 79 & ND & - & 80 & ND & - \\
\hline October & 81 & ND & - & ND & ND & - & 44 & ND & - \\
\hline November & 108 & 27 & 25 & 229 & ND & - & 342 & 86 & 25 \\
\hline
\end{tabular}

